\title{
Adeno-Associated Virus Type 2
}

National Cancer Institute

\section{Source}

National Cancer Institute. Adeno-Associated Virus Type 2. NCI Thesaurus. Code C48818.

This strain of viridae is a non-pathogenic human parvovirus that is icosahedral, $20-25 \mathrm{~nm}$

in diameter, minus sense, and comprised of a $5 \mathrm{~kb}$. single-stranded DNA genome. The virus is generally monomorphic and has been developed as a gene therapy vector for the treatment of numerous diseases. Wild-type AA-2 retains the ability to preferentially integ rate its DNA into a 4 kilobase region of human chromosome 19, designated AAVS1, making it an attractive gene therapy vehicle. The virus has demonstrated anti-cancer activity by inducing apoptosis and inhibiting the growth of cancer cells. 